\title{
Markasan Strategy in A Best-Selling Music
}

\author{
Rully Aprilia Zandra ${ }^{\bowtie}$ \\ Department of Arts, Drama, Dance and Music, Faculty Languages and Arts, \\ Universitas Negeri Malang, Indonesia
}

Received: March 18, 2019. Revised: May 7, 2019. Accepted: June 23, 2019

\begin{abstract}
Gesang and Didi Kempot, in dominating the market of the music industry in their era, incorporated local capital, i.e., the site in lyrics and scales in melody. Likewise with Markasan. However, little is known about the site and melody used by Markasan as a tool to dominate the keroncong market in East Java in the 1960-1965 period. This study aims to reveal lyrics and melody that songwriters can use to dominate the music competition market in their day. To address this gap, observations, interviews, and documentation studies were carried out. The subjects are Keroncong-Markasanan musicians and RRI as melting pots of keroncong in Surabaya. Through 'Blauran Wayah Sore' song, we can observe Markasan's efforts to construct songs, build resistance, and perpetuate domination in the music industry competition in his day. This research provides a strategy to utilize cultural capital consisting of lyric styles, popular site names, local scales, and identification of favorite song scales in a best-selling effort in the music industry today.
\end{abstract}

Keywords: scales, lyrics, music, keroncong, strategy

How to Cite: Zandra, R. A. (2019). Markasan Strategy in A Best-Selling Music. Harmonia: Journal of Arts Research And Education, 19(1), 55-61.

\section{INTRODUCTION}

Gesang was a famous keroncong (Indonesian music adapted from Portuguese) composer; his works are not only popular domestically, but also worldwide. Among the phenomenal works by Gesang is Bengawan Solo. The lyrics and melody of this song are easily acceptable by many (Sanjaya, 2018). The strength of the lyrics lies in the way it explains a place in Solo (Dirgantara, 2014), which is similar to what Didi Kempot did.

Didi Kempot is a composer of campursari keroncong and singer. He often incorporates famous places, such as Tirtonadi Terminal and Stasiun Balapan, in the lyrics of his songs, which are mostly about love sto- ries (Laksono, 2015). Gesang's renowned Bengawan Solo and Didi Kempot's famous Stasiun Balapan and Terminal Titonadi have dominated the local market music; both composers incorporated the name of a famous site in their song lyrics (Khoir, 2016; Sarwinah, 2016).

The lyrics of the songs correlate with the messages explaining several public places in Solo. Love stories and social situations at the iconic places of selected cities are the themes of the songs. The selection of the public places, such as Bengawan Solo, Terminal Tirtonadi, and Stasiun Balapan, is because the places are closely related to daily activities of the audience (Sarwinah, 2016). Anyone who have heard of Bengawan Solo river, Terminal Tirtonadi,

\footnotetext{
Corresponding author:

E-mail: rullyzandra.fs@um.ac.id
} 
and Stasiun Balapan are probably people who come from cities other than Solo, such as tourists.

Other than the lyrics and the melodies, the composers of the songs are wellknown for their works that are easy to understand and sing (Dirgantara, 2014). The melodies remain popular among people (Widjajadi, 2005). Kusnaidi (2015) opines that melodies and lyrics are the charms of every song. The song by the two composers is easy to imitate. Based on the preliminary observation involving 30 respondents (ten children, ten teens, and ten adults), $86.6 \%$ of the respondents can imitate the cantus firmus of the song right in the second chorus.

On that ground, the study on melodies in the songs mentioned above is worth investigating. It is to examine how the songs can dominate the chart during its era. The concern indicates the necessity to examine the lyrics and melodies developed by the composer. A keroncong music group, namely Markasan, which emphasized delivering attractive lyrics and melodies, has been established in Surabaya; it was on the top chart of the best keroncong song. The name of this keroncong orchestra is Aneka Warna, which was led by Markasan (Zandra, 2014). The genre of this style of keroncong is called Markasanan (Sulistiohadi, 2000).

Keroncong was first developed in Surabaya in 1942 during the East Asia War, that was when Japan invaded countries that the Netherlands colonized (Widodo, 2002). At the time, Japan gave the freedom to people to develop local music, including keroncong, to eliminate all western cultures in Indonesia (Yacob, 2017). This genre of music has spread in areas other than East Java in Indonesia since 1942. In 1960, RRI (the national radio of Indonesia) had run a keroncong music program (Zandra, 2014). This initiative further stimulated the establishment of keroncong groups, with many composers competed with each other in the music industry (Widjajadi, 2005).

Markasan's keroncong orchestra has its uniqueness (Sulistiohadi, 2000). It is po- pular for its chord, stem, and beat that differs the Markasan keroncong with other styles, such as old keroncong, Jakarta style, and Solo style (Zandra, 2019). Other distinguishing characteristics are its lyrics. The lyrics of the old keroncong, Jakarta style, and Solo style are mostly about the appreciation of nature and heroes, while the Markasan style emphasizes social critics, description of landmarks and public places, and social interaction (Zandra, 2014).

The development of Markasan keroncong went on hiatus in the middle of 1965 for two years due to the 30 September movement by the Communist Party of Indonesia or PKI (Zandra, 2019). This study focused on the 1960 to 1965 period or the golden age of Markasan keroncong. In 1960, Leo Ledung, the first Markasan keroncong album, was released. The golden era of Markasan ended in 1965; this was also the last year for Markasan to lead the OK Aneka Warna keroncong group (Zandra, 2014, 2019).

In several songs, Markasan often mentioned several landmarks or public places in Surabaya, e.g., Tugu Pahlawan, Jalan Tunjungan, and Pasar Blauran. Pasar Blauran (a traditional market) is a famous market to date. The melodies of Markasan's works associated with the trending music at Surabaya, such as Remo and Jula-Juli. Concerning the above discussion, it is found that Markasan has his methods and strategies in composing his trending music from 1960 to 1965 . These methods and strategies are the inspiration of the song Blauran Wayah Sore, a keroncong song and the icon of keroncong music in Surabaya.

The present study, underpinned by the above discussion, is aimed at exploring the way Markasan utilized the power of incorporating public places and landmarks in his easy-listening songs. It is intended to map the lyrics and melodies of the composers and its utilities that brought the music to be the trending music in its era.

\section{METHODS}

This qualitative study employed a 
case study approach. Documentation and recording method was used to collect the data. It focused on gathering information related to the lyrics of the songs, popular places, tunes in Markasan, and popular tunes in society. This process was by transcribing texts and audio of Markasan and Jula-Juli songs and investigating the popular public places incorporated in the songs. Several stages of data collection in the field was attempted to maximize the effectiveness of the process.

The first method was the passive involvement; this stage involved observation of the rehearsal and repertoire of the Surabayan keroncong in RRI for six months. It was to record the response of the musicians regarding Markasan and his ideas and other information related to the problem of the study.

The second method was by an unstructured interview with composers and musicians of keroncong who have the opportunity to collaborate with Markasan. All questions were to ensure the accuracy of information retrieved from the respondents. The respondents were informed about the purpose of the interview before the researcher began to ask the questions. The method was performed reversely to those who have a differing opinion with Markasan.

A library study was carried out to generate information regarding the concepts of the research object; this method was also to prevent similarities with the previous studies. Information was retrieved from books, journals, research reports, and other printed documents; the data included the one from the internet regarding the development of keroncong in Surabaya and the figure of Markasan and his works. The data were in the form of the musical note transcription from the vinyl record, photos, images, audio recording, videos, and cassettes. The transcription process was done using the Sibelius 7 application.

All of the collected data were grouped based on the focus of this research. The classification involved the style of the lyrics, landmarks, tunes of Markasan song, and tunes of pop songs. After crosschecking the data with the relevant literature and the concepts of habitus, arena, mimicry, and hybrid, these data were presented to find out the answers to the research questions.

\section{RESULTS AND DISCUSSION}

The lyrics and melodies of a song Blauran Wayah Sore incorporate the cultural value of the Markasan song. In this context, the value refers to the lyrics and the pentatonic scale. The satire lyrics are inspired by a keroncong song Liedje, a song about social critics. The pelog and slendro pentatonic scale was from the folk music or accompanying music in parikan (Javanese rhymes) and other dances. Satire lyrics of Liedje keroncong are integrated into Wajik Abang keroncong in Surabaya, or a song telling the embezzlement of government vehicles committed by civil servants. The car is known for its red diamond symbol on its side part of the mirror. The vehicle is supposed to operate from Monday to Friday. However, the car is now used on Sunday. Satire lyrics in the song mentioned above are to criticize the misuse of state assets for personal gain. The straightforward characteristics are also visible in keroncong wajik by Markasan, emphasizing the popularity of Aneka Warna orchestra from 1960 to 1965.

Folk music, parikan, and accompaniment track of Remo dance form an aural environment for Markasan since he was a child. Further, the aforementioned aural environment raised Marksan's cultural capital in the form of musical ideas, abilities, and cultural codes. His cultural code is shown in his artwork. Intentionally or unintentionally, through a proper introduction to the arena of his work, Markasan has incorporated the local cultural capital in the flow of cultural imports.

Associated with efforts to resist a culture in The Location of Culture (Bhaba, 1994), it is explained that the cultural contexts colonizers and colonized people influence each other. Both have similarities 
in terms of resistance and anxiety. Bhaba further describes that the solutions to these problems lie in the culture of survival strategy carried out by each group of the people. The survival strategy carried out by the colonized parties by utilizing the culture of the colonizers through imitation, and cultural transformation produce a local culture with a hybrid identity. Hybrid identity can be uncomplicatedly seen on Markasan's Keroncong (Javanese song) style because the Netherlands and Japan had colonized Surabaya.

The above condition links the similarity of Markasan's research to the concept of Bhaha, which also seeks to examine the form of local cultural resistance reflected in imported instrumentation. The text that mentions the local place was reflected in the lyrics of Kerocong. The common tone scale for Jula-Juli (one of the Javanese rhyme styles) is integrated into the Keroncong entity, which has the characteristic of European-style music. Keroncong music's entity in its hybrid form has a mimicry camouflage strategy and produces an identity that mixes local culture with imported culture (Bhaba, 1994; Haryatmoko, 2010; Jenkins, 1992; Zandra, 2014). The hybridity of Markasan's works was his foresight in using the music tastes of post-colonial society and wrapping them in popular music commodities at that time.

While in The Interpretation of Cultures: Selected Essays explained that political modernization from the beginning tended not to be calming (Geertz, 1973). The transition from sovereignty to an independent regime is more than a shift of power from foreign hands to indigenous'. The third worlds' political themes of cultural perspectives examined by Geertz involve nationalism of new countries, primordial sentiments, civil politics, and cultural politics. Greetz also gave a concept to this research in considering Markasan's ideas from the cultural politics in the 1960-1965 era.

His power strategy that has been found in discussions and data analysis is the concepts of lyrics and scales. His lyrics contents are the portraits of demographics, psychology, geography, daily social situations and places in Surabaya (Bourdieu, 1993; Zandra, 2014). Due to its too-visible characteristics, these portraits are not considered special. However, according to history, Liedje' Keroncong easily received popularity precisely by presenting common social portraits. Nowadays, Terminal Tirtonadi and Stasiun Balapan by Didi Kempot also take the local sites as the lyrics' parts and easily dominate the market. Gesang also had success using Bengawan Solo song to gain popularity. In the same context, Markasan's power strategy on the concept of lyrics was allegedly also obtained from his expertise in utilizing social portraits and places in Surabaya. As one example of the song Blauran Wayah Sore both in the title and the lyrics mention the name Blauran Market. Activities in Blauran Market also become reproductions of environmental portraits described in detail throughout the lyrics. The concept of Blauran Wayah Sore's lyrics is a reproduction of environmental portraits and sites used by Markasan to gain popularity.

The satirical, straightforward, and critical language style in the lyrics of his song is also the communal utterances in Surabaya. Therefore, it can be said that the concept of the lyrics the songs is not new but a reproduction from what already exists. Markasan personal development and thoughts are inseparable from the influence of the surrounding environment. The environment, which was the satirical, straightforward, and critical environment, was formed since his childhood. This is evident in the satire, straightforward, and critical lyrics of Liedje Keroncong that existed long before the Markasan era. The situation depicted in the lyrics of Keroncong Liedje persisted as a satirical, straightforward, and critical speech style of the people of Surabaya to date. This kind of habitus builds the cultural capital of Markasan's lyrics. The cultural capital of Markasan's lyrics makes the lyricist a satirical, straightforward, and critical style. Likewise, the time context covered the connection of the people surrounding when the community 
was familiar with satire, straightforward, and critical. It can also be said that there is a link between popular song lyric writing strategies and their environmental background and context. In other words, the analysis of objective structure cannot be separated from the analysis of the origin of the mental structure of the individual who wrote the lyrics. And the analysis of objective structures cannot be separated from the analysis of the origin of the individual mental structures of the prospective audience (Bourdieu, 1993; Haryatmoko, 2010).

The battle of strength and strategy in the Keroncong music industry results in conditions for taking positions between dominance and subordination of cultural capital at stake (Jenkins, 1992; Zandra, 2019). At this point, what happens is power relations between social agents who then form social classes consisting of class structures that dominate and be dominated. As a result, the structured symbolic violence mechanism appears due to Markasan's efforts in implementing Surabaya local cultural capital ownership strategy. This strategy is evident in the distinction of Markasan against S. Padimin or other keroncong songwriters in Surabaya (Haryatmoko, 2010). Distinction raised by Markasan is self-affirmation as the dominant class to distinguish themselves from other social classes. His lyrics styles were his dominant trademarks and castes that intentionally created and defended to win the Keroncing music industry in 1960-1965.

Habitus and capital concept in winning the industry assist this research in figuring out the use of Blauran Wayah Sore song as one of the assets that preserve OK Aneka Warna directed by Markasan. The other relation between his ideas and habitus was also seen in his scales. The scales played by OK Aneka Warna were reproduction and imitation from Surabaya's Jula-Juli's scales. Moreover, by $1-1-1-1$ - 1 interval scales, the scales are in accompaniment track of Eastern Javanese dance such as ludruk, parikan's melody, gamelan, or macapatan's melody.

Thus, the hybrid idea is reflected in keroncong song that has European tone colors with Surabaya's places and scales. Markasan used Surabaya's lyric style to dominate the music industry in Surabaya in the 1960-1965 era. All of them were reproductions and imitations of things that already exist in the music lovers community in Surabaya. They were easily and quickly approved by the people who were basically familiar with the local structure that was re-uploaded in the form of Blauran Wayah Sore song.

In this case, Markasan style was originally formed by the environment, which in turn, shapes the tastes of the environment and Surabayans precisely (Bourdieu, 1993; Jenkins, 1992; Zandra, 2014). His success reproduced the environment in the form of lyrics content on the place in the song still needs to be appreciated because not everyone can do it, the success of this reproduction is also a success to meet the tastes and market demands (Eleanor, 2009). Bourdieu explained that the dialectic between actors and systems could only be created and perpetuated by social actors conditioning the product and system relations that surround them (Bourdieu, 1990; Bourdieu \& Johnson, 1993).

Based on the data collected, Markasan is considered to be very free to express himself in his work; his music writing strategy associated with the local auditory culture capitals of Surabaya he has. Additive cultural capital in the form of pelog scale was borrowed by Markasan to grab market appetites quickly. Market tastes can be called the pelog scale because the scale of the pelog is an easy listening scale for the aspiring audience of song lovers. Pelog scale borrowing strategy in the success of dominance in the music industry at that time automatically perpetuated pelog scale capital in the industry. The strategy and outcomes of the pelog scale domination process were the contributions of Markasan in perpetuating the subject's habitus. Whether realized or not, the situation of the relationship between ideas in the work and the structure in its environment is the right strategy to perpetuate the style of ly- 
rics and the scale of Surabaya's melody. Both of them also succeeded in extending the duration of habitus in the Surabaya environment. The perpetuation of habitus in the environment automatically builds the durability of permanent community tastes. If the people's tastes still like satirical, straightforward, and critical lyrics, then songwriter strategies that use satirical, straightforward, and critical styles will continue to sell. If the people's tastes remain on the pelog tone scale, then the keroncong songwriter who uses the pelog tone scale will also continue to sell. That is, if a dominant songwriter can maintain his market tastes, then he will still be able to dominate the market with the same strategy.

Markasan used the power of the site in song lyrics and proved to be the dominant class. He used satirical, straightforward, and critical styles in social stories that placed in the background of popular places and dominated the market as well. Hence, it can be concluded that the strategy of lending lyrics style and borrowing popular places' names are two smart ways to maintain or gain market dominance in the music industry. Markasan also employed the easy listening pelog scale for the people of Surabaya. He also recognized that the people of Surabaya at that time were still familiar with the scale of the pe$\log$ tone. So it concludes that borrowing the local tone scale and identifying the scale of the community's favorites is the third and fourth way to win in the music industry in each market. The style of lyrics, popular places' names, local scales, and identification of favorite tone scales are four of Markasan's smart strategies for becoming the best-selling songwriter of his time.

\section{CONCLUSIONS}

From the above discussion, this study concludes that Markasan lived in the East Java environment, which is close to the popular and music sites of Jala-Juli. The cultural capital carried by Markasan is the concept of a site habitus portrayed gradually from its physical and social environment, and the concept of musical habitus that surrounds it over a long period. The concept of the place created the lyric text 'Blauran market.' While the musical concept sparked melody in the pelog scales. These ideas are representations of lending style lyrics, popular places' names, local scales, and identification of favorite tone scales of Surabaya's cultural structure. This study also provides strategies to utilize cultural capital in the form of lyric styles, popular places' names, local scales, and identification of favorite song scales for songwriters to excel in the music industry today.

\section{REFERENCES}

Bhaba, H. K. (1994). The Location of Culture. New York: Routledge.

Bourdieu, P. (1990). Reptoduction in Education, Society, and Culture. London: Routledge.

Bourdieu, P. (1993). The Field of Cultural Production. London: Routledge.

Bourdieu, P., \& Johnson, R. (1993). The Field of Cultural Production: Essays on Art and Culture (p. 322). p. 322. https:// doi.org/9780231082860

Dirgantara. (2014). Analisis Lagu Bengawan Solo [Analysis of the Song of Bengawan Solo]. Digilib ISI Yogyakarta, 1-9.

Eleanor, B. (2009). Homi, K. Bhabha, Transition. Palgrave Macmillan, London.

Geertz, C. (1973). The Interpretation of Cultures: Selected Essays. New York: Basic Book. Inc.

Haryatmoko. (2010). Dominasi Penuh Muslihat Akar Kekerasan dan Diskriminasi [Deception Domination: The Origin of Violence and DIscrimination]. Jakarta: Gramedia.

Jenkins, R. (1992). Pierre Bourdieu, Key Sociologist. London: Routledge.

Khoir, M. (2016). Mengidentifikasi Segmen Pasar dan Memilh Pasar Sasaran [Identifying Market Segment and Market Target]. AKADEMIKA, 10(June). 
Laksono, J. T. (2015). Perspektif Historis Campursari Dan Campursari Ala Manthou'S [Historical Perspective of Campursari and Manthou's Campursari]. Imaji, 8(1). https://doi. org/10.21831/imaji.v8i1.6654

Sanjaya, S. (2018). New Composition Concept for Keroncong Music in the Oboe Concerto with Keroncong and Orchestra. International Journal of Creative and Arts Studies, 5(2), 7585. https://doi.org/10.24821/ijcas. v5i2.2413

Sarwinah. (2016). Relevansi Nilai Sastra Pada Lirik Lagu Ridwan Sau Dengan Kondisi Sosial Budaya Masyarakat Kota Makassar (Suatu Pendekatan Struktural Genetik) [The Relevance of Literature Value in the Lyrics of the Song Ridwan Sau of the Culture of Makasar City Citizen: A Genetic Structural Approach]. Konfiks: Jurnal Bahasa Dan Sastra Indonesia, 1(1), 92. https:// doi.org/10.26618/ jk.v1i1.164

Sulistiohadi. (2000). Perkembangan Musik Keroncong Siaran RRI Surabaya Tahun 1960 hingga Tahun 1999 [The Development of Keroncong in RRI
Surabaya from 1960 to 1999]. Gelar, Jurnal Seni I FBS.

Widjajadi, R. A. S. (2005). Menelusuri Sarana Penyebaran Musik Keroncong [The History of the Spread of Keroncong]. Harmonia: Journal of Arts Research and Education, 6(2).

Widodo, D. I. (2002). Soerabaia tempo Dulu [The Past Story of Surabaya]. Surabaya: Dinas Pariwisata.

Yacob, S. (2017). Hirosima/Nagasaki: Mangsa Propaganda Sejarah [Hiroshima/Nagasaki: The Victim of Historical Propaganda]. Sejarah: Journal of Departement of History.

Zandra, R. A. (2014). Sejarah Musik Keroncong di Surabaya [The History of Keroncong in Surabaya]. Imaji, 12(1), 74-84.

Zandra, R. A. (2019). Keroncong Gaya Keempat (Kajian Bentuk dan Gaya Penyajian) [The Fourth Style of Keroncong: A Study of the Form and Presentation]. Journal of Art, Design, Art Education And Culture Studies (JADECS), 4(1), 39-47. Retrieved from http:// journal2.um.ac.id/index.php/dart/ article/view/ 8133/4405 